\title{
Charakter prawny odpowiedzialności za nieszczepienie dziecka
}

\author{
Legal nature of liability for non-vaccinating a child \\ Правовая природа ответственности за отказ от вакцинации ребенка
}

\author{
SEBASTIAN CZECHOWICZ \\ Doktorant, Uniwersytet Łódzki \\ e-mail: sebastianczechowicz.official@gmail.com, https://orcid.org/0000-0002-1770-1941
}

\begin{abstract}
Streszczenie: Obowiązkowe szczepienia ochronne stanowią podłoże rozlicznych dyskusji i kontrowersji nie tylko wśród społeczeństwa, lecz także w środowisku socjologów, epidemiologów, jak i prawników. Obowiązek poddawania się szczepieniom dotyczy przede wszystkim dzieci, a więc jego wykonanie spoczywać będzie na prawnych lub faktycznych opiekunach małoletniego. W ostatnich latach odnotowuje się wzrost odsetka liczby niezaszczepionych dzieci. Uchylanie się od obowiązku szczepień obecnie stanowi coraz większy problem społeczny i prawny. Niniejszy artykuł jest poświęcony problematyce odpowiedzialności za uchylanie się od obowiązkowych szczepień ochronnych w ujęciu dogmatyki prawa karnego sensu largo. Wykazane związki pomiędzy działalnością administracji publicznej a współczesnym prawem wykroczeń, które penalizuje uchylanie się od obowiązku szczepień, pomogą zrozumieć wielopłaszczyznową strukturę wzajemnych zależności pomiędzy aktualnie wyodrębnionymi gałęziami prawa. Tym samym uwypuklając mieszany charakter odpowiedzialności za niewykonywanie obowiązkowych szczepień ochronnych.
\end{abstract}

Słowa kluczowe: odpowiedzialność za wykroczenie, przymus administracyjny, obowiązek szczepień, uchylanie się od obowiązkowych szczepień ochronnych

Summary: Mandatory vaccinations are the basis for numerous discussions and controversies not only among the public but also among sociologists, epidemiologists, and lawyers. The obligation to undergo vaccinations primarily concern children, so it will be performed by the legal or factual guardians of the minor. In recent years, there has been an increase in the proportion of children not vaccinated. Avoiding the obligation to vaccinate is currently an increasing social and legal problem. This article is devoted to the issue of responsibility for the evasion of compulsory vaccination in terms of criminal law dogma. The demonstrated links between the activity of public administration and the contemporary law of offence, which penalises the evasion of the obligation to vaccinate, will help to understand the multi-faceted structure of mutual relations between the currently separated branches of law. This highlights the mixed nature of the responsibility for not carrying out mandatory preventive vaccination.

Key words: criminal liability, administrative coercion, obligation to vaccinate, evasion of compulsory preventive vaccination

Резюме: Обязательные профилактические прививки являются основой многочисленных дискуссий и споров не только среди общества, но также среди социологов, эпидемиологов и юристов. Обязанность пройти вакцинацию касается в основном детей, поэтому ее выполнение возлагается на законных или фактических опекунов несовершеннолетнего. В последние годы наблюдается увеличение процента невакцинированных детей. Уклонение от обязанности вакцинации в настоящее время является растущей социальной и правовой проблемой. Настоящая статья посвящена вопросу ответственности за уклонение от обязательной вакцинации с точки зрения догматики уголовного права sensu largo. Продемонстрированные взаимосвязи между деятельностью органов государственного управления и современным законодательством в отношении проступков, предусматривающим криминализацию уклонения от 
обязанности вакцинации, помогут понять многогранную структуру взаимных зависимостей между выделяемыми в настоящее время отраслями права. Таким образом, подчеркивается смешанный характер ответственности за невыполнение обязательной вакцинации.

Ключевые слова: ответственность за проступок, административное принуждение, обязанность вакцинации, уклонение от обязательной вакцинации

\section{Wstęp}

Obowiązek szczepień w Polsce normowany jest ustawą z dnia 5 grudnia 2008 r. o zapobieganiu oraz zwalczaniu zakażeń i chorób zakaźnych u ludzi ${ }^{1}$. Polega on na poddaniu obowiązanego przedszczepiennemu badaniu kwalifikacyjnemu, a następnie (po stwierdzeniu braku przeciwskazań do zaszczepienia) czynności zaszczepienia ${ }^{2}$. Zgodnie $z$ aktualnym orzecznictwem sądów administracyjnych ${ }^{3}$ trzeba zauważyć, że na obowiązek szczepień składa się nie tylko sam zabieg polegający na zaszczepieniu, ale i przedszczepienne lekarskie badanie kwalifikacyjne. Zakres przedmiotowy i podmiotowy tego obowiązku skonkretyzowany został w rozporządzeniu Ministra Zdrowia $\mathrm{z}$ dnia 18 sierpnia $2011 \mathrm{r}$. w sprawie obowiązkowych szczepień ochronnych ${ }^{4}$.

W ostatnich latach niepoddawanie dzieci szczepieniom obowiązkowym stanowi dość zauważalny problem natury przede wszystkim społecznej. W efekcie sytuacja nabrała tempa i w 2018 r. złożono do Sejmu RP obywatelski projekt ustawy o zmianie ustawy o zapobieganiu oraz zwalczaniu zakażeń i chorób zakaźnych u ludzi ${ }^{5}$. Aktualnie szacuje się, że od obowiązku szczepień uchyliło się kilkadziesiąt tysięcy osób ${ }^{6}$. Przeciwnicy szczepień podnoszą nie tylko argumenty zawarte we

1 Tekst jednolity: Dz. U. z 2020 r. poz. 1845 z późn. zm.

2 Szerzej np. M. Boratyńska, Szczepienia ochronne, w: Regulacja prawna czynności medycznych, t. 2, cz. 1, red. M. Boratyńska, P. Konieczak, Warszawa 2019, s. 740-744.

3 Wyrok NSA z dnia 6 czerwca 2017 r., II GSK 2399/15, LEX nr 2341038.

4 Tekst jednolity: Dz. U. z 2018 r. poz. 753.

5 Druk Sejmowy nr 2796 złożony dnia 28 sierpnia 2018 r. W projekcie tym podnoszono konieczność zniesienia obowiązku szczepień ochronnych i zastąpienia go dobrowolnością szczepień, argumentując, że istniejący obowiązek pozbawia rodziców i dzieci godności osoby ludzkiej, a także naraża na wystąpienie Niepożądanych Odczynów Poszczepiennych (NOP). Wskazywano także na naruszanie prawa do prywatności i decydowania o życiu osobistym, a także odwoływano się do zasady autonomii jednostki, wiążąc ją z nakazem poszanowania godności osoby ludzkiej. Do tego projektu krytyczne opinie wyraziły m.in. Naczelna Rada Lekarska czy Prezydium Naczelnej Rady Pielęgniarek i Położnych.

6 Rok rocznie raporty z realizacji obowiązku szczepień są publikowane przez Narodowy Instytut Zdrowia Publicznego - Państwowy Zakład Higieny (PZH). Z informacji PZH wynika, że w 2010 r. zanotowano 3437 odmów, w 2017 r. już 30089 odmów. Informacje za lata 2018-2019 są jeszcze bardziej niepokojące. Wskazuje się, że w 2018 r. liczba ta przekroczyła $40000 \mathrm{z}$ tendencją wzrostową w roku 
wspomnianym obywatelskim projekcie ustawy, lecz wskazują na przypadki zachorowań na różne choroby (w tym autyzm), które wiążą oni jednoznacznie z wykonanym szczepieniem. Zaznaczenia wymaga fakt, że obowiązek szczepień należy rozpatrywać rozłącznie od ewentualnego występowania NOP, które wynikają z reakcji organizmu na podanie konkretnego składu chemicznego szczepionki, nie są tożsame dla każdego organizmu i nie występują powszechnie. Procedurę w sprawie stwierdzenia wystąpienia niepożądanych odczynów poszczepiennych określa stosowne rozporządzenie Ministra Zdrowia ${ }^{7}$.

Obowiązek szczepień jest przedmiotem dyskusji także na gruncie nauk prawnych. Obserwując wyniki postępowań sądowo-administracyjnych i skargi składane do Trybunału Konstytucyjnego, można dopatrywać się pewnych nieścisłości w zakresie jego konstytucyjności. Ponadto zauważyć należy, że aktualna konstrukcja regulacji prawnych składających się na obowiązkowe szczepienia ochronne w Polsce nastręcza również wielu trudności interpretacyjnych, także co do określenia przynależności do konkretnej gałęzi prawa. Wobec tego jako zasadna jawi się konieczność dokonania analizy dogmatyczno-prawnej w zakresie ustalenia charakteru prawnego odpowiedzialności za nieszczepienie dziecka.

\section{Ocena aktualności koncepcji prawa karno-administracyjnego i administracyjno-karnego w kontekście obowiązkowych szczepień ochronnych}

Na wstępie należy podkreślić, że w obecnych czasach nie występują takie formy odpowiedzialności jak: karno-administracyjna ${ }^{8}$ czy administracyjno-karna. Funkcjonowały one w polskiej rzeczywistości prawnej wXX w., niejako łącząc sferę prawa administracyjnego z prawem karnym sensu largo. W literaturze wskazywano na pozytywne aspekty funkcjonowania prawa karno-administracyjnego, gdyż stanowiły ,jeden system karno-wychowawczy”, który łączył orzecznictwo organów

następnym. W najnowszym raporcie za 2020 r. wskazuje się, że odsetek niezaszczepionych przekroczył 50000 przypadków.

7 Rozporządzenie Ministra Zdrowia z dnia 21 grudnia 2010 r. w sprawie niepożądanych odczynów poszczepiennych oraz kryteriów ich rozpoznawania, Dz. U. z 2010 r. Nr 254, poz. 1711.

8 Szerzej np. M. Łysko, Przełom roku 1956 w Polsce a orzecznictwo karno-administracyjne, Zeszyty Prawnicze 2011, nr 11(4), s. 277-305. 
różnego typu9. Mimo walorów tego systemu podnoszono jednocześnie wątpliwości dotyczące przygotowania prawniczego obsady kolegiów orzekających na gruncie prawa karno-administracyjnego, były to bowiem organy administracji publicznej ${ }^{10}$. Obawy pojawily się także na gruncie ewentualnej kolizji postępowań (karnego i karno-administracyjnego $)^{11}$. Co istotne w kontekście prowadzonych rozważań, prowadzony od ubiegłego wieku spór o materialną istotę wykroczenia ${ }^{12}$, które niejako konstytuuje się na styku prawa administracyjnego, jednocześnie przynależąc aktualnie do prawa karnego sensu largo, jest aktualny także i obecnie.

W literaturze przedmiotu podnosi się, że koncepcja prawa karno-administracyjnego ewoluowała $\mathrm{w}$ prawo wykroczeń $\mathrm{w}$ latach 70 . ubiegłego stulecia ${ }^{13}$. Do 1971 r. bowiem nie istniało skodyfikowane prawo wykroczeń, które prowadzone było w oparciu o odrębną procedurę (obecnie: postępowanie w sprawach o wykroczenia prowadzone przed sądem karnym ${ }^{14}$. To organy administracji publicznej pełniły rolę quasi sądu z uprawnieniami do karania. Prawo administracyjne poza dyspozycjami i określeniem pożądanych zachowań czy stanów rzeczy miało także sankcje administracyjnoprawne noszące cechy represji znanej obecnie w prawie karnym i prawie wykroczeń. Sprowadzało się to do możliwości wydawania orzeczeń zaopatrzonych nie tylko w sankcje przymuszające do wykonania obowiązku, ale i nieuchronne sankcje natury represyjnej. Po zmianach legislacyjnych kolegia orzekające w sprawach o wykroczenia zostały zlikwidowane, a ustawodawca przeniósł orzekanie w tej materii na sądy karne. Koncepcja prawa karno-administracyjnego zdawała się w tym przypadku upaść. Doktryna prawa (w szczególności karnego i administracyjnego) dostrzegła jednak pewne zależności, które - pomimo licznych zmian legislacyjnych - pozostały w praktyce stosowania prawa. Administracji publicznej pozbawionej możliwości karania w tych sprawach pozostawiono

9 W.F. Dąbrowski, Społeczne uwarunkowanie norm prawa karno-administracyjnego, Ruch Prawniczy, Ekonomiczny i Socjologiczny 1970, z. 1, s. 80.

10 Por. M. Cieślak, Uwagi na marginesie projektu prawa o orzecznictwie karno-administracyjnym, Palestra 1961, t. 5, nr 6 (42), s. 40.

11 S. Waltoś, Kolizja postępowania karnego i karno-administracyjnego, Palestra 1961, t. 5, nr 12 (48), s. 22.

12 A. Marek, Istota i zasady odpowiedzialności karnej za wykroczenia: na tle ustawy o przekazaniu niektórych drobnych przestępstw do orzecznictwa karno-administracyjnego, Palestra 1967, t. 11, nr 5(113), s. 85 .

13 D. Szumiło-Kulczycka, Prawo administracyjno-karne, Kraków 2004, s. 21.

1420 maja 1971 r. uchwalono obowiązujący obecnie K.w., co przesądziło o zmianie kierunku ustawodawstwa krajowego w zakresie oddzielenia administracji od prawa wykroczeń. Co prawda do 2001 r. działały jeszcze kolegia rozpatrujące sprawy wykroczeń, jednakże 24 sierpnia 2001 r. wprowadzenie Kodeksu postępowania w sprawach o wykroczenia jednoznacznie wyraziło postawę ustawodawcy o przeniesieniu tego zakresu spraw pod jurysdykcję sądów karnych. 
jednak sankcje mające na celu przymuszenie do wykonania obowiązku, a także administracyjne kary pieniężne ${ }^{15}$.

Stawiane pytanie: czy administracja publiczna ma kompetencje do karania i w jaki sposób może tego dokonywać, jest kwestią problematyczną. Zachowując pewną nadrzędność nad obywatelem obowiązanym do wykonania nałożonego obowiązku o charakterze prawnym, organy administracji powinny mieć środki do wyegzekwowania tej powinności, lecz owe środki egzekucyjne nie są karami. Tu właśnie toczony jest spór o charakter i funkcje (te rzeczywiste i ukryte ${ }^{16}$ ) nakładanych sankcji administracyjnoprawnych o charakterze pieniężnym. Między innymi $\mathrm{z}$ tego powodu w nauce prawa funkcjonuje pojęcie prawa administracyjno-karnego, czyli ogółu regulacji prawnych, które obejmują ustanowienie i dochodzenie odpowiedzialności za naruszenia norm administracyjnoprawnych, zagrożonych sankcją np. w postaci kary pieniężnej czy podobnej sankcji realizowanej przed organem administracji publicznej w postępowaniu administracyjnym ${ }^{17}$.

15 Zależności pomiędzy prawem administracyjnym a prawem karnym sensu largo, w poczet którego zalicza się prawo wykroczeń, dostrzegła także D. Danecka, wykazując liczne przykłady konwersji odpowiedzialności na gruncie tych dwóch gałęzi prawa. D. Danecka, Konwersja odpowiedzialności karnej w administracyjna w prawie polskim, Warszawa 2018.

16 Jak jeszcze funkcja ochronna polegająca na ochronie dobra prawnego za pomocą obwarowania sankcją administracyjną nie podlega większej dyskusji, tak funkcja represyjna, która przejawia się w karaniu za zachowanie będące sprzeczne $\mathrm{z}$ prawem (w tym przypadku z nałożonym obowiązkiem), bywa dyskusyjne, gdyż administracja publiczna co do zasady uprawnień sądu w zakresie karania nie posiada. Jednak ze względu na specyfikę relacji i zaszłości prawnych między sferą administracji, a obecnie ukształtowanym prawem wykroczeń należy poprzeć twierdzenie wyrażone $\mathrm{w}$ wyroku TK z dnia 15 stycznia 2007 r., P19/06, w którym wskazano, co następuje: „wątpliwości dotyczące charakteru kar wymierzanych przez organy administracji, występowały w przeszłości w doktrynie zarówno prawa karnego, jak i prawa administracyjnego. Formułowane były nawet krańcowo rozbieżne poglądy uznające owe kary albo za instrumenty administracyjne, albo za prawnokarne. Z uwagi na dolegliwość finansową, kary orzekane przez sądy wykazują podobieństwo do kar pieniężnych nakładanych przez organy administracji. Istota tkwi jednakże w odmiennych funkcjach, które spełniają obie formy represji państwa. Kara administracyjna nie jest bowiem odpłatą za popełniony czyn, lecz stanowi środek przymusu służący zapewnieniu realizacji wykonawczo zarządzających zadań administracji. Widoczne jest to zwłaszcza po wyodrębnieniu prawa wykroczeń, a więc prawa dotyczącego czynów karalnych ściganych uprzednio $\mathrm{w}$ trybie postępowania określanego jako karno-administracyjne, $\mathrm{w}$ odrębną gałąź w systemie prawa karnego. Wykroczenie określone jako czyn bezprawny, społecznie niebezpieczny, zawiniony i zabroniony jest przecież naruszeniem obowiązków prawnych, zbliżonym rodzajowo znacznie bardziej do przestępstwa niż do uchybienia dyrektywom prawnoadministracyjnym”. Można zatem stwierdzić, iż sankcje administracyjne posiadają ukrytą funkcję represyjną, mającą na celu zagwarantowanie wykonania dyspozycji przepisu, z wyjątkiem nieopłaconych pieniężnych sankcji egzekucyjnych, które umarza się w przypadku spełnienia obowiązku (art. $125 \$ 1$ ustawy o postępowaniu egzekucyjnym w administracji, tekst jednolity: Dz. U. z 2020 r. poz. 288).

Tamże, s. 29. 
Wskazać należy na niewątpliwie trafną diagnozę L. Staniszewskiej, która zauważa, że administracyjne kary pieniężne rozważane były w doktrynie jako instytucje na styku prawa administracyjnego, prawa finansowego i prawa karnego ${ }^{18}$. Trafnie także przed laty stwierdził J.S. Langrod, że administracja wielokrotnie działa „jak sędzia", rozstrzygając spory pomiędzy stronami o przeciwstawnych interesach, ale także orzeka w sprawach karnych ${ }^{19}$. Szczegółową analizę doktryny w zakresie problematyki sankcji administracyjnych o charakterze pieniężnym prowadził M. Wincenciak, powołując się na F. Lonchampsa i J. Jędrośkę. Wskazywał on przy tym, że w doktrynie prawa administracyjnego prowadzona była dyskusja na temat umiejscowienia prawa karno-administracyjnego $\mathrm{w}$ systemie polskiego prawa ${ }^{20}$. Należy przy tym odróżnić ten termin od pojęcia prawa karno-administracyjnego, które mimo podobnej nazwy jest znaczeniowo różne.

Pomimo wielu niespójności w realizacji całkowitego wyodrębnienia prawa wykroczeń izerwania z koncepcją prawa karno-administracyjnego do tej pory napotkać można takie określenie. Chociażby w najnowszym orzecznictwie Sądu Najwyższego (dalej: SN) doszukać można się stwierdzenia, jakoby uchylanie się od obowiązku szczepień rodziło odpowiedzialność karno-administracyjną stypizowaną w art. 115 $\$ 1$ K.w. ${ }^{21}$. Także w nieco starszym orzeczeniu Trybunału Konstytucyjnego (dalej: TK) z dnia 15 stycznia 2007 r. pojawia się następujące określenie: „widoczne jest to zwłaszcza po wyodrębnieniu prawa wykroczeń, a więc prawa dotyczącego czynów karalnych ściganych uprzednio w trybie postępowania określanego jako karno-administracyjne, w odrębną gałąź w systemie prawa karnego" ${ }^{22}$. Jednoznacznie zatem $\mathrm{w}$ dalszym ciągu sfera prawa administracyjnego łączona jest z prawem wykroczeń, pomimo jego ustawowego wyodrębnienia, co jest oczywiście uzasadnione specyfiką prawa wykroczeń.

Zastanowić należy się jednak nad charakterem wywodu przedstawionego przez SN na kanwie sprawy o wykroczenie polegające na uchyleniu się od poddania

18 L. Staniszewska, Kodyfikacja administracyjnej kary pieniężnej jako instrumentu prawnego na styku z odpowiedzialnością karna, w: Prawo administracyjne dziś i jutro, red. J. Jagielski, M. Wierzbowski, Warszawa 2018, s. 197.

19 J.S. Langrod, Instytucje prawa administracyjnego. Zarys części ogólnej, Kraków 2003, s. 34 i nn.

20 Szerzej M. Wincenciak, Sankcje w prawie administracyjnym i procedura ich wymierzania, Warszawa 2008, s. 22 i nn.

21 Na kanwie sprawy V KK 306/15 dotyczącej wykroczenia z art. $115 \$ 2$ K.w., a więc uchylania się od obowiązkowych szczepień ochronnych, SN posłużył się następującym określeniem: „Zaniechanie poddania się obowiązkowemu szczepieniu, mimo zastosowania środków egzekucji administracyjnej rodzic odpowiedzialność karno-administracyjną przewidzianą w art. $115 \$ 1$ k.w.". Sugeruje to ciągłe istnienie zależności pomiędzy organami administracji publicznej a nowożytnym prawem wykroczeń, zob. wyrok SN z dnia 8 stycznia 2016 r., V KK 306/15, LEX nr 1963649. Wyrok TK z dnia 15 stycznia 2007 r., P19/06, LEX nr 232287. 
dziecka obowiązkowemu szczepieniu ochronnemu. Niewątpliwie budzi zastrzeżenia posługiwanie się historycznym już określeniem prawa „karno-administracyjnego". Rozważyć jednak trzeba, czy specyfika polskiego systemu obowiązkowych szczepień ochronnych nie daje podstaw do możliwości określenia ponoszonej odpowiedzialności tak w sferze administracyjnoprawnej, jak i prawa wykroczeń. Z tego już dostrzec można rozmyty (niejednolity) model obowiązkowych szczepień ochronnych.

Przywołane powyżej orzeczenia nadają sens dalszej analizie w kontekście realizacji obowiązku szczepień w Polsce, pomimo że termin „odpowiedzialność karno-administracyjna" ma charakter historyczny ${ }^{23}$, tak próba przejścia do prawa wykroczeń akurat $\mathrm{w}$ tym przypadku jest niepełna i stanowczo mało precyzyjna do jednoznacznego odczytania miejsca obowiązku szczepień w polskim prawie publicznym (administracyjnym i karnym).

Przedmiotowe zagadnienie należy też rozpatrzeć z innej perspektywy. Jak wskazano, obowiązkowe szczepienia ochronne regulują przepisy prawa administracyjnego. Jednakże odpowiedzialność za niepoddanie się obowiązkowej immunizacji przewiduje już Kodeks wykroczeń (dalej: K.w.). Sugerując się wypracowaną w doktrynie prawa definicją, przez prawo administracyjno-karne rozumie się ogół regulacji prawnych, które obejmować będą zarówno ustanawianie, jak i dochodzenie odpowiedzialności z tytułu naruszenia norm prawa administracyjnego, obwarowanych sankcją w postaci kary pieniężnej czy też podobnej sankcji finansowej realizowanej w administracyjnym postępowaniu i przed administracyjnym organem ${ }^{24}$. Analizując tę definicję pod kątem omawianego obowiązku, dostrzec można następujące zbieżności:

1) obowiązek szczepień uregulowany został w prawie administracyjnym,

2) niepoddanie się obowiązkowym szczepieniom ochronnym dochodzone jest $\mathrm{w}$ trybie postępowania egzekucyjnego $\mathrm{w}$ administracji,

23 Warto dodać, że próbę skorygowania tego terminu podjęto już w doktrynie polskiego prawa. W. Radecki zaproponował nazwanie go „administracyjnym prawem karnym” (W. Radecki, Kategoryzacje czynów zabronionych pod groźba kary w prawie polskim, czeskim i słowackim, cz. 2, Ius Novum 2012, $\mathrm{nr} 3$, s. 9), natomiast R.A. Stefański zasugerował nazwanie go mianem „prawo administracyjne karne” (R.A. Stefański, Prawo karne materialne. Część ogólna, Warszawa 2008, s. 25). Zdaje się nie być dostatecznie precyzyjnej nazwy tego prawa, które przenika zarówno prawo administracyjne, jak i prawo wykroczeń, należące obecnie do prawa karnego sensu largo. Trudności nastręcza także pozostawienie w kompetencjach administracji możliwości stosowania administracyjnych kar pieniężnych, które noszą cechy represji za niewykonanie obowiązku czy zachowanie sprzeczne z prawem administracyjnym. Tym bardziej jaskrawo rysuje się obowiązek szczepień, który ma swoje podstawy prawne w prawie administracyjnym, lecz sankcje za niepodporządkowanie się temu obowiązkowi przewiduje już prawo wykroczeń.

24 D. Szumiło-Kulczycka, Prawo administracyjno-karne..., s. 29. 
3) nakładane grzywny mają na celu przymuszenie do wykonania ciążącego obowiązku, nie stanowią jednak kary za jego niezrealizowanie. Zatem zaliczyć je można do grupy „finansowych sankcji podobnych”.

Istnieje jednak zasadnicza rozbieżność. Mianowicie odpowiedzialność za uchylenie się od obowiązkowego szczepienia ochronnego jest ponoszona na gruncie prawa wykroczeń, nie natomiast w postępowaniu administracyjnym. Daje to powody do odrzucenia tego modelu.

Problem pojawia się w momencie nieskutecznej próby egzekucji obowiązku przez organy administracji publicznej. Wówczas następuje swoiste przeniesienie ciężaru karania za uchylenie się od obowiązkowych szczepień ochronnych na sąd karny, gdyż czyn ten stypizowany jest jako wykroczenie na podstawie art. 115 K.w. Istotnie, element „dochodzenia do odpowiedzialności realizowanej $\mathrm{w}$ administracyjnym postępowaniu i przed administracyjnym organem" pozostawia wiele wątpliwości. O ile sankcję administracyjną możemy zakwalifikować jako pewną dolegliwość o charakterze prawnym, mającą na celu - w tym przypadku przełamanie oporu obowiązanego i nakłonienie go do wykonania ciążącego na nim obowiązku, tak zbyt szerokie rozumienie tego rodzaju sankcji, a zatem zrównanie sankcji z karaniem, nastręczyłoby wiele trudności interpretacyjnych i zbytnio uogólniłoby samo rozumienie przedmiotowego pojęcia. Implikuje to twierdzenie, że odpowiedzialność zaistnieje dopiero na gruncie prawa karnego sensu largo, czyli w tym przypadku - odpowiedzialność na gruncie prawa wykroczeń. Można wnioskować także, że jest to zgodne z zamysłem ustawodawcy, który reformami zapoczątkowanymi w 1971 r., a trwającymi praktycznie do lat dwutysięcznych, przeniósł „karanie”, a więc i „odpowiedzialność” do prawa wykroczeń, jednocześnie ujednolicając drogę pociągnięcia do odpowiedzialności - mianowicie postępowanie w sprawach o wykroczenia.

Zestawiając powyższe rozważania ze wspomnianym wcześniej orzecznictwem sądowym, dojść można do wniosku, że łączenie obowiązku szczepień tylko i wyłącznie z prawem karnym albo jedynie z prawem administracyjnym byłoby daleko idącym uogólnieniem. Przyjęcie koncepcji prawa administracyjno-karnego jawi się jako mało precyzyjne ze względu na wspomniany brak sankcji w regulacjach administracyjnoprawnych, przez co nie można mówić o odpowiedzialności podmiotu obowiązanego na gruncie prawa administracyjnego. Ponadto obowiązek ten nie jest obwarowany konkretną sankcją finansową innego typu, nakładanie bowiem grzywny w celu przymuszenia do wykonania obowiązku stosowane jest na podstawie ogólnych przepisów ustawy o postępowaniu egzekucyjnym w administracji ${ }^{25}$. 
Zasadnie wskazać trzeba na liczne zbieżności z doktryną prawa administracyjno-karnego, lecz nader istotny fakt ponoszonej odpowiedzialności na gruncie prawa wykroczeń, a nie w postępowaniu administracyjnym, co jednoznacznie przesądza o nieadekwatności posługiwania się terminem prawa „administracyjno-karnego” na prezentowanym przykładzie.

Pomimo że na pozór zerwano z koncepcją prawa karno-administracyjnego na rzecz prawa wykroczeń, to prawo administracyjne i wykroczenia pozostają nadal w ścisłym korelacie, co widoczne jest nie tylko na przykładzie obowiązkowych szczepień ochronnych. Wartościowym w tej materii wydaje się cytowany już wyrok SN, w którym jednoznacznie wskazano, iż uchylenie się od obowiązkowych szczepień ochronnych rodzi „odpowiedzialność karno-administracyjną” przewidzianą w art. 115 K.w.

Wydaje się zasadne skłaniać do poglądu obrazującego obowiązek szczepień $\mathrm{w}$ perspektywie pomiędzy prawem administracyjnym a prawem karnym sensu largo, jednak $\mathrm{z}$ uwzględnieniem braku sankcji w prawie administracyjnym $\mathrm{i}$ jednoczesnym braku podstawy prawnej realizacji obowiązku szczepień w prawie wykroczeń.

Sugerując się określeniem SN, jakoby uchylenie się od poddania dziecka obowiązkowemu szczepieniu ochronnemu rodzi odpowiedzialność „karno-administracyjną", zauważyć należy, że odpowiedzialność tego typu w polskim prawie aktualnie nie istnieje. Jednakże, $\mathrm{w}$ związku z przedstawioną specyfiką systemu regulacji prawnych określających funkcjonowanie obowiązkowych szczepień ochronnych, powołanie się na tę nazwę wydaje się słuszne, jeśli mowa o mieszanym charakterze modelu obowiązku szczepień w Polsce. Odczytywanie analizowanego na gruncie niniejszego opracowania orzeczenia $\mathrm{SN}$ w ten sposób pozwala na wyinterpretowanie ogólnego sensu stanowiska SN, wskazującego na ogół regulacji prawnych składających się na obowiązek szczepień. Wydaje się to być jedynym słusznym rozumieniem wywodu SN. Tym samym można zatem twierdzić, iż obowiązkowe szczepienia ochronne w obecnym kształcie prawnym w doktrynie prawa można rozważać jako obowiązek o charakterze karno-administracyjnym ${ }^{26}$.

26 Jak wskazuje D. Szumiło-Kulczycka, prawo karno-administracyjne stanowi pod postacią prawa wykroczeń trzeci filar prawa karnego sensu largo, natomiast w opozycji stoi prawo administracyjno-karne, które jest samoistną formą odpowiedzialności administracyjno-prawnej. (D. Szumiło-Kulczycka, Prawo administracyjno-karne..., s. 118). 


\section{Próba ustalenia możliwości uznania uchylania się od obowiązkowych szczepień ochronnych za delikt administracyjny}

Podczas analizy omawianego problemu nie sposób nie odnieść go do pojęcia deliktu administracyjnego. Próba analizy tego terminu w odniesieniu do procederu uchylania się od obowiązkowych szczepień ochronnych pozwoli na ocenę, czy w ogóle możemy mówić o delikcie administracyjnym polegającym na uchyleniu się od obowiązku szczepień, czy też nie.

$\mathrm{W}$ literaturze przedmiotu, a także $\mathrm{w}$ orzecznictwie natrafić można na różne rozumienie pojęcia deliktu administracyjnego. Wskazuje się, że jest to działanie podmiotu, które narusza obowiązujące prawo i zagrożone jest sankcją administracyjną ${ }^{27}$. D. Danecka definiuje delikt administracyjny jako tylko takie naruszenie norm prawa publicznego, które zagrożone jest administracyjną karą pieniężną ${ }^{28}$. Ciekawy pogląd zaprezentowała A. Błachnio-Parzych, która zaliczyła delikty administracyjne do odpowiedzialności represyjnej i określiła je pojęciem „deliktu penalnego”, za który grozi odpowiedzialność administracyjno-karna ${ }^{29}$. W orzecznictwie natomiast wykazano, że istota odpowiedzialności administracyjnej sprowadza się do tego, że aby pociągnąć do niej określony podmiot, konieczne jest zaistnienie dwóch przesłanek. Pierwszą jest konieczność posiadania cech przez podmiot, które wyrażone są w normie prawnej stanowiącej podstawę odpowiedzialności. Po drugie natomiast, podmiot ten musi wyczerpać określone w tej normie znamiona działania lub zaniechania lub znamiona tegoż zachowania muszą zostać wyczerpane przez inny podmiot, o ile norma prawna przypisuje zachowanie innego podmiotu lub skutek tego zachowania wspomnianemu podmiotowi. Zaistnienie powyższych przesłanek w ocenie Wojewódzkiego Sądu Administracyjnego w Poznaniu jest wystarczające, by doszło do poniesienia odpowiedzialności za delikt administracyjny ${ }^{30}$. Wyraźnie zatem wiąże się odpowiedzialność za delikt administracyjny z przewidzianą sankcją w postaci kary pieniężnej ${ }^{31}$.

Przyjmując zatem, że deliktem administracyjnym jest naruszenie norm prawa administracyjnego, które zagrożone jest administracyjną karą pieniężną, można

27 M. Wincenciak, Sankcje w prawie administracyjnym..., s. 93.

28 D. Danecka, Konwersja odpowiedzialności..., s. 91.

29 A. Błachnio-Parzych, Zbieg odpowiedzialności karnej i administracyjno-karnej jako zbieg reżimów odpowiedzialności represyjnej, Warszawa 2016, s. 32.

30 Wyrok WSA w Poznaniu z dnia 27 czerwca 2014 r., III SA/Po 1619/13, LEX nr 1486250.

31 Por. uchwała NSA z dnia 10 kwietnia 2006 r., I OPS 1/06, LEX nr 182508; wyrok NSA z dnia 28 sierpnia 2008 r., I FSK 972/07, LEX nr 469028; wyrok WSA z dnia 17 maja 2011 r., VII SA/Wa 2430/10, LEX nr 1097695. 
dojść do jednoznacznego wniosku, że obowiązek szczepień w obecnym kształcie prawnym niczym go nie przypomina. Nie ma określonej sankcji w prawie administracyjnym za uchylenie się od obowiązkowych szczepień ochronnych, więc nie spełnia on kryteriów definicyjnych deliktu administracyjnego. Jak już wspomniano, nakładanie grzywien $w$ toku postępowania egzekucyjnego jest jedynie formą przymuszenia podmiotu obowiązanego do poddania się temu obowiązkowi, nie zaś karą za jego złamanie, obowiązek bowiem ciągle istnieje i podmiot administrowany musi go spełnić, by nie narazić się na kolejną grzywnę w celu przymuszenia do spełnienia tego obowiązkuª ${ }^{32}$. Można zatem $\mathrm{z}$ całą mocą stwierdzić, iż obowiązek szczepień posiadając swoje umocowanie w przepisach prawa administracyjnego, nie posiadając sankcji w postaci administracyjnej kary pieniężnej, nie może być rozpatrywany w kontekście możliwości popełnienia deliktu administracyjnego, gdyż sankcja za niepodporządkowanie się temu obowiązkowi została ustanowiona w prawie karnym sensu largo, a konkretniej w prawie wykroczeń.

\section{Model odpowiedzialności za uchylanie się od obowiązkowych szczepień ochronnych - między prawem administracyjnym a prawem karnym}

Skoro nawet SN posłużył się w aktualnym orzecznictwie dotykającym problemu uchylania się od obowiązkowych szczepień ochronnych stwierdzeniem o karno-administracyjnej odpowiedzialności za nieszczepienie, warto skupić się na próbie wyprowadzenia ogólnego modelu odpowiedzialności za ten czyn. Stanąć należy na stanowisku, iż obowiązek szczepień, który w swej aktualnej formie uregulowany jest w przepisach polskiego prawa, nie ma charakteru jednolitego i nie można zakwalifikować go do jednej gałęzi prawa. Pomimo iż normy określające ten obowiązek bezsprzecznie znajdują się w prawie administracyjnym, tak w jego normach nie można doszukać się sankcji za uchylenie się od tego obowiązku. Co więcej, istnienie sankcji w celu przymuszenia do jego wykonania na podstawie ustawy o postępowaniu egzekucyjnym w administracji nie stanowi sankcji za niewykonanie obowiązku.

Odpowiedzialność za uchylenie się od obowiązkowych szczepień ochronnych została przeniesiona na grunt prawa wykroczeń, który w dzisiejszych czasach

32 Na mocy art. 121 ustawy o postępowaniu egzekucyjnym w administracji grzywnę w celu przymuszenia można stosować wielokrotnie, jednakże każdorazowo grzywna ta wynosić może do $10000 \mathrm{zł}$, a łącznie nałożone grzywny nie mogą przekroczyć kwoty 50000 zł. 
stanowi w Polsce odrębną gałąź prawa, a ogólniej - należy do prawa karnego sensu largo. Wynika z tego, że obowiązek szczepień ma niejednolity charakter. Nie można także stwierdzić, że obowiązek ten zaszeregować można do prawa wykroczeń ze względu na określony w art. 115 K.w. wzorzec penalizowanego zachowania. Przepisu art. 115 K.w. nie należy czytać w oderwaniu od norm prawa administracyjnego określającego sam obowiązek. Dopiero razem stanowią swoisty korelat, z którego wywieść można: istnienie obowiązku zabezpieczonego sankcją za jego niewykonanie, zakres podmiotowy i przedmiotowy tego obowiązku, charakter obowiązku szczepień i wreszcie jego egzekucję. Ponadto art. 115 K.w. nie może być zastosowany bez uprzedniej aktywności organów administracji publicznej, zgodnie bowiem z treścią tego przepisu: „Kto, pomimo zastosowania środków egzekucji administracyjnej [...] podlega karze grzywny do 1500 złotych albo karze nagany". Zatem dopiero zastosowanie środków egzekucji administracyjnej, czyli najpierw istnienie obowiązku w prawie administracyjnym, a następnie nieskuteczne działanie organów administracji publicznej w sferze zewnętrznej doprowadzi do aktualizacji odpowiedzialności na gruncie prawa wykroczeń ${ }^{33}$. A contrario odpowiedzialności tej nie będzie podlegała osoba, wobec której nie zastosowano środków egzekucji administracyjnej, pomimo że uchyliła się od obowiązku. Przesłanka uprzedniego działania administracji publicznej w celu wyegzekwowania obowiązku szczepień jest immanentnym składnikiem pociągnięcia do odpowiedzialności za wykroczenie $\mathrm{z}$ art. $115 \$ 1$ lub 2 K.w.

Dokonując próby ustalenia modelu odpowiedzialności za uchylanie się od obowiązkowych szczepień ochronnych, stwierdzić należy następujące fakty:

1) podstawy prawne obowiązku szczepień znajdują się w prawie administracyjnym,

2) egzekucja tego obowiązku prowadzona jest w trybie postępowania egzekucyjnego w administracji,

3) sankcja za uchylanie się od obowiązkowych szczepień ochronnych określona została w prawie wykroczeń i jej zastosowanie związane jest $\mathrm{z}$ uprzednim działaniem organów administracji publicznej,

4) odpowiedzialność za uchylenie się od obowiązku szczepień powstaje poprzez wystąpienie przez kompetentny organ administracji publicznej z wnioskiem

33 Szerzej na temat odpowiedzialności za uchylanie się od obowiązkowych szczepień ochronnych np. R. Kubiak, Konsekwencje administracyjne i karne stosowane wobec rodziców sprzeciwiających się obowiązkowym szczepieniom ochronnym w: Zagadnienia prawa medycznego, red. A. Górski, E. Sarnecka, Warszawa 2018, s. 95-107; A. Fiutak, Odpowiedzialność przedstawiciela ustawowego za niewykonanie szczepienia obowiazkowego, Medyczna Wokanda 2017, nr 9 (9), s. 155-169; I. Jaworska, Odmowa zaszczepienia dziecka i jej konsekwencje prawne, Przegląd Prawa Publicznego 2017, nr 3, s. $60-72$. 
o ukaranie do sądu karnego, a wymierzenie sankcji karnej za ten czyn następuje na drodze postępowania w sprawach o wykroczenia.

Na podstawie tego schematu widać wyraźnie wspomnianą niejednolitą strukturę prawną obowiązku szczepień. Przenika on jednocześnie prawo administracyjne i nowożytne prawo wykroczeń, stanowiąc dużą trudność w wyinterpretowaniu, jaki ma charakter prawny. Można wywodzić, iż jeżeli de facto jest to wykroczenie, to odpowiedzialność za to jest skumulowana w prawie wykroczeń, zatem wniosek może być tylko jeden: modelem odpowiedzialności za nieszczepienie będzie odpowiedzialność za wykroczenie. Jednakże, czy w przypadku analizy przepisu art. 115 K.w. można mówić o samodzielności w stosowaniu prawa? Pozostaje tu wiele wątpliwości, szczególnie zważając na argumenty przedstawione w niniejszym wywodzie. Nie powinno się przyjmować samodzielnej, oderwanej od źródła prawnego pochodzenia obowiązku szczepień podstawy prawnej do wymierzenia sankcji za nieszczepienie w postaci art. 115 K.w., gdyż on sam odsyła w swoich znamionach do weryfikacji przez sąd karny, czy zastosowano uprzednio środki egzekucji administracyjnej.

Rozważając o modelu obowiązkowych szczepień ochronnych w Polsce, należy mieć na uwadze wspomniane czynniki. Ponadto rozumienie analizowanego stanowiska SN w kontekście nazwania systemu obowiązkowych szczepień ochronnych „karno-administracyjnym” nie pozostaje w sprzeczności z aktualną nomenklaturą doktryny polskiego prawa. Istotnie, odpowiedzialności za uchylenie się od obowiązkowego szczepienia ochronnego na gruncie prawa administracyjnego nie ma. Lektura art. 115 K.w. naprowadza na konieczność szerszego (systemowego) postrzegania tego obowiązku. Idąc za tym, zauważyć należy, że zbyt szerokie rozumienie stanowiska SN doprowadziłoby do błędnego rozumienia stwierdzenia o „karno-administracyjnej odpowiedzialności” za nieszczepienie, przez co niezgodnego z aktualnie obowiązującą systematyką prawa powszechnie obowiązującego. Wydaje się zatem zasadna interpretacja, że „karno-administracyjna odpowiedzialność” nie oznacza odpowiedzialności na gruncie prawa administracyjnego i prawa karnego sensu largo, lecz niesie za sobą rozumienie odpowiedzialności na gruncie prawa wykroczeń ściśle korelującego z podstawą prawną umiejscowioną w prawie administracyjnym. Przez to model obowiązkowych szczepień ochronnych na tle niektórych państw europejskich ma w Polsce charakter mieszany (karno-administracyjny).

Obowiązek szczepień w Polsce i jego charakter prawny jest jaskrawym przykładem na ciągłe istnienie karno-administracyjnego myślenia ustawodawcy bądź niekonsekwencji w oddzieleniu administracji od ukształtowanego na przełomie XX i XXI w. nowożytnego prawa wykroczeń. W tym przypadku jednak należy mieć na uwadze aktualne podstawy prawne obowiązku szczepień, przez co wywodzić 
można, jednocześnie skłaniając się ku sformułowaniu zastosowanemu przez SN w cytowanym wcześniej orzeczeniu, iż odpowiedzialność za uchylanie się od obowiązku szczepień ma charakter „karno-administracyjny”. Zaznaczyć trzeba, że wspomniana przez $\mathrm{SN}$ forma charakteru tego obowiązku nie jest historycznym rozumieniem tego terminu. Wydaje się, iż jeżeli w trakcie argumentacji odpadają przesłanki za kwalifikowaniem tego obowiązku jako delikt administracyjny czy obowiązek o charakterze administracyjno-karnym, to można mówić o mieszanej naturze tego obowiązku. Przy czym mowa tu o rozumieniu tego pojęcia zgodnie $\mathrm{z}$ doktryną prawa administracyjno-karnego, a więc opatrzenie obowiązku w sankcję finansową jakiegokolwiek typu. Tym samym skoro obowiązek szczepień posiada sankcje go zabezpieczające w różnych aktach prawnych (Kodeksie wykroczeń, ustawie o postępowaniu egzekucyjnym $\mathrm{w}$ administracji) należących do różnych gałęzi prawa, można rozważać ten obowiązek przez pryzmat jego mieszanego charakteru prawnego. Zasadną zatem jawi się aprobata dla sformułowania wyrażonego przez SN w 2016 r., ale także wcześniejsze cytowane orzeczenie TK z 2007 r., w którym także odwołano się do tego terminu. Widać przy tym wyraźnie, jak wielkie trudności interpretacyjne sprawia niejednolitość prawna obowiązkowych szczepień ochronnych i kwestia odpowiedzialności za uchylenie się od tego obowiązku.

Przyjmując stanowisko, że charakter prawny obowiązku szczepień jest rozmyty, łącząc prawo administracyjne z prawem wykroczeń, wypada podnieść, iż pomimo stosowania sankcji w trybie postępowania w sprawach o wykroczenia, obowiązkowe szczepienia ochronne stanowią wyraz wykazanej zaszłości prawnej, która nie została po dziś dzień rozstrzygnięta. Dodać przy tym należy, że pomimo istnienia wykroczeń wynikających z niepodporządkowania się normom prawa administracyjnego obowiązkowe szczepienia ochronne są specyficznym przykładem, w szczególności jeśli porównać modele obowiązku szczepień z innymi krajami europejskimi. W tym zakresie należy dostrzec potrzebę weryfikacji aktualnie obowiązującego modelu szczepień obowiązkowych w stosunku do jego efektywności na gruncie praktycznego stosowania prawa.

Mając na uwadze powyższe, wydaje się adekwatne twierdzić, że obowiązkowe szczepienia ochronne posiadając podstawę prawną obowiązywania w prawie administracyjnym, a sankcję za niepodporządkowanie się temu obowiązkowi w prawie wykroczeń, dają wyraźny asumpt do stwierdzenia, że forma odpowiedzialności sensu largo, a więc podstaw prawnych obowiązku i jego egzekwowania oraz wymierzania sankcji za niepodporządkowanie się temu obowiązkowi, stanowi model mieszany: karno-administracyjny. 


\section{Zakończenie}

Obowiązkowe szczepienia ochronne stanowią niewątpliwie problem na gruncie teorii i praktyki prawa. Mając na uwadze cel szczepień, jakim jest ochrona społeczeństwa przed szerzeniem się chorób zakaźnych, normy prawne kształtujące ten obowiązek należy odczytywać łącznie. Tylko wówczas dostrzegalny jest kształt modelu obowiązkowych szczepień ochronnych w Polsce. Jak wywiedziono, ma on charakter mieszany, można powiedzieć - rozmyty. Konstytuując się na styku prawa wykroczeń i prawa administracyjnego, nastręcza trudności przede wszystkim w praktyce funkcjonowania.

W teoretycznym ujęciu problemu wyraźnie widać, że mieszany charakter prawny obowiązku może powodować wątpliwości i różne jego rozumienie na gruncie praktyki stosowania prawa. Posługiwanie się historycznym nazewnictwem w kontekście odpowiedzialności za uchylanie się od obowiązkowych szczepień ochronnych może doprowadzić do wielu interpretacji. Jednej, stanowiącej o błędnym nazwaniu charakteru tej odpowiedzialności, a drugiej - dostrzegającej raczej nazwanie charakteru systemu realizacji obowiązku szczepień w Polsce, a nie traktującej „odpowiedzialności karno-administracyjnej” przez pryzmat jej przeszłego znaczenia i historycznej systematyki polskiego prawa.

Podsumowując, zaznaczyć trzeba, że pomimo określenia modelu obowiązkowych szczepień ochronnych w Polsce jako mieszany (karno-administracyjny) nie ulega wątpliwości, że odpowiedzialność prawna sensu stricte wynika z prawa wykroczeń stypizującego wykroczenie polegające na uchylaniu się od obowiązkowych szczepień ochronnych. Jednakże prowadząc rozważania o ogóle regulacji prawnych składających się na obowiązek szczepień ochronnych w Polsce, nie mogą zejść z pola widzenia regulacje administracyjnoprawne statuujące przedmiotowy obowiązek. Dopiero całościowe ujęcie prezentowanej tematyki na tle historyczno-prawnym pozwoliło wywieść prezentowane wnioski o mieszanym modelu obowiązkowych szczepień ochronnych w Polsce.

\section{Bibliografia}

Błachnio-Parzych A., Zbieg odpowiedzialności karnej i administracyjno-karnej jako zbieg reżimów odpowiedzialności represyjnej, Warszawa 2016.

Boratyńska M., Szczepienia ochronne, w: Regulacja prawna czynności medycznych, t. 2, cz. 1, red. M. Boratyńska, P. Konieczak, Warszawa 2019. 
Cieślak M., Uwagi na marginesie projektu prawa o orzecznictwie karno-administracyjnym, Palestra 1961, t. 5, nr 6 (42).

Danecka D., Konwersja odpowiedzialności karnej w administracyjna w prawie polskim, Warszawa 2018.

Dąbrowski W.F., Społeczne uwarunkowanie norm prawa karno-administracyjnego, Ruch Prawniczy, Ekonomiczny i Socjologiczny 1970, z. 1.

Fiutak A., Odpowiedzialność przedstawiciela ustawowego za niewykonanie szczepienia obowiązkowego, Medyczna Wokanda 2017, nr 9 (9).

Jaworska I., Odmowa zaszczepienia dziecka i jej konsekwencje prawne, Przegląd Prawa Publicznego 2017, nr 3.

Kubiak R., Konsekwencje administracyjne i karne stosowane wobec rodziców sprzeciwiajacych się obowiązkowym szczepieniom ochronnym, w: Zagadnienia prawa medycznego, red. A. Górski, E. Sarnecka, Warszawa 2018.

Langrod J.S., Instytucje prawa administracyjnego. Zarys części ogólnej, Kraków 2003.

Łysko M., Przełom roku 1956 w Polsce a orzecznictwo karno-administracyjne, Zeszyty Prawnicze 2011, nr 11 (4).

Marek A., Istota i zasady odpowiedzialności karnej za wykroczenia: na tle ustawy o przekazaniu niektórych drobnych przestępstw do orzecznictwa karno-administracyjnego, Palestra 1967, t. 11, nr 5(113).

Staniszewska L., Kodyfikacja administracyjnej kary pieniężnej jako instrumentu prawnego na styku z odpowiedzialnością karna, w: Prawo administracyjne dziś i jutro, red. J. Jagielski, M. Wierzbowski, Warszawa 2018.

Stefański R.A., Prawo karne materialne. Część ogólna, Warszawa 2008.

Szumiło-Kulczycka D., Prawo administracyjno-karne, Kraków 2004.

Radecki W., Kategoryzacje czynów zabronionych pod groźbą kary w prawie polskim, czeskim i słowackim, cz. 2, Ius Novum 2012, nr 3.

Waltoś S., Kolizja postępowania karnego i karno-administracyjnego, Palestra 1961, t. 5, nr 12 (48).

Wincenciak M., Sankcje w prawie administracyjnym i procedura ich wymierzania, Warszawa 2008. 